\title{
Health benefits of subcutaneous zinc edetate and diphenyl diselenide in calves during the weaning period
}

\author{
DAIANE S. DOS SANTOS ${ }^{1}$, JHONATAN P. BOITO ${ }^{1}$, VANDERLEI KLAUCK ${ }^{2}$, JOÃO H. DOS \\ REIS $^{1}$, ROGER R. GEBERT ${ }^{1}$, PATRÍCIA GLOMBOWSKY ${ }^{1}$, ANGELISA H. BIAZUS ${ }^{2}$, NATHIELI \\ B. BOTTARI ${ }^{3}$, REJANE S. SOUSA ${ }^{4}$, GUSTAVO MACHADO ${ }^{5}$, MARTA L.R. LEAL ${ }^{6}$, MATHEUS \\ D. BALDISSERA ${ }^{7}$, JEAN C. BERWANGER ${ }^{8}$ and ALEKSANDRO S. DA SILVA ${ }^{1,2}$
}

${ }^{1}$ Departamento de Zootecnia, Universidade do Estado de Santa Catarina/UDESC, Rua Beloni Trombeta Zanin, 680D, 89815-630 Chapecó, SC, Brazil

${ }^{2}$ Programa de Pós-Graduação em Zootecnia, Universidade do Estado de Santa Catarina/ UDESC, Rua Beloni Trombeta Zanin, 680D, 89815-630 Chapecó, SC, Brazil

${ }^{3}$ Departamento de Bioquímica e Biologia Molecular, Universidade Federal de Santa Maria/ UFSM, Avenida Roraima, 1000, 97105-900 Santa Maria, RS, Brazil

${ }^{4}$ Departamento de Bioquímica e Biologia Molecular, Universidade de São Paulo/ USP, Avenida Prof. Lineu Prestes, 748, 05508-000 São Paulo, SP, Brazil

${ }^{5}$ Department of Veterinary Population Medicine, College of Veterinary Medicine, University of Minnesota, Gortner Ave, 1365, St. Paul, 55108 MN, USA

${ }^{6}$ Departamento de Grandes Animais, Universidade Federal de Santa Maria/UFSM, Avenida Roraima, 1000, 97105-900 Santa Maria, RS, Brazil

${ }^{7}$ Departamento de Microbiologia e Parasitologia, Universidade Federal de Santa Maria/ UFSM, Avenida Roraima, 1000, 97105-900 Santa Maria, RS, Brazil

${ }^{8}$ Graduação em Medicina Veterinária, Universidade Norte do Paraná/UNOPAR, Avenida Paris, Jardim Piza, 675, 86083-070 Londrina, PR, Brazil

Manuscript received on December 31, 2017; accepted for publication on June 12, 2018

How to cite: SANTOS DS ET AL. 2019. Health benefits of subcutaneous zinc edetate and diphenyl diselenide in calves during the weaning period. An Acad Bras Cienc 91: e20171042. DOI 10.1590/0001-3765201920171042.

\begin{abstract}
The aims of this study were to investigate whether treatments with zinc edetate (Zn) and diphenyl diselenide $\left((\mathrm{PhSe})_{2}\right)$ enhance performance, immune responses, protein metabolism, and oxidant/ antioxidant status in calf serum and muscle. Animals were divided into four groups ( $\mathrm{n}=6$ each): control (without supplementation), and groups supplemented on days 50 and 70 of life with $(\mathrm{PhSe})_{2}, \mathrm{Zn}$, and a combination of $(\mathrm{PhSe})_{2}$ and $\mathrm{Zn}$. Animals treated with $(\mathrm{PhSe})_{2}$ gained more weight by experimental day 220 than did the control group, but there was no difference by the end of the experiment (day 300). The absolute number of leukocytes and lymphocytes increased in groups $\mathrm{Zn}$ and $(\mathrm{PhSe})_{2}+\mathrm{Zn}$ on day 20 of experiment, but decreased on day 40 in groups $(\mathrm{PhSe})_{2}$, and $(\mathrm{PhSe})_{2}+\mathrm{Zn}$. The number of monocytes decreased in all groups compared with control. One of the principal findings was that $(\mathrm{PhSe})_{2}+\mathrm{Zn}$ together had beneficial effects on protein metabolism, represented by increases total protein and globulin levels, compared with the control group. The combination of (PhSe) $)_{2}$ and $\mathrm{Zn}$ led to low levels of TBARS and ROS in serum and muscle, and stimulated antioxidant enzyme activities. Thus, supplementation with $(\mathrm{PhSe})_{2}+\mathrm{Zn}$ may be a compelling approach to augmenting the calf antioxidant system during weaning.
\end{abstract}

Key words: calves, zinc edetate, $(\mathrm{PhSe})_{2}$, animal health.

Correspondence to: Aleksandro Schafer da Silva

E-mail: aleksandro_ss@yahoo.com.br

ORCid: https://orcid.org/0000-0002-6940-6776 


\section{INTRODUCTION}

The breeding phase forcalves, leading up to weaning, is a period of maximal profit for the producer, since this is when greatest feed conversion occurs (Silper et al. 2014). Farms that focus on dairy production sell male calves to meat producers, who fatten the animals for later slaughter. Normally, calves arrive at meat-producing farms on the first day of life, having consumed only colostrum. Investigators describe good potential for short-term weight gain in Holstein calves at this stage (Biondi et al. 1984).

The breeding phase begins with artificial feeding, where exclusive milk-based formula may lead to underdevelopment of the rumen (Kolb et al. 1984). To avoid this, many producers practice early weaning, allowing the animal to start its life as a ruminant earlier, since newborn calves have similar digestive systems to dwarf ruminants. In addition, as they require nutrients for development, they begin to ingest solids, accelerating the development of the rumen and consequently digesting more fiber (Braga et al. 2006). However, it should be emphasized that the liquid diet is a pleasurable experience for the calf and the end of this phase causes physiological stress, in addition to reduction in dry matter consumption (12\% milk dry matter $\mathrm{x}$ milk volume supplied). Energy and protein deficiency can cause a reduction in energy balance if concentrate consumption does not increase rapidly (Tzou et al. 1991, Davis and Drackley 1998). The metabolic stress related to weaning may be severe, causing the calves to consume their own energy and protein reserves, resulting in oxidative stress (Sundrum 2015). Oxidative stress is defined as an imbalance between the production and elimination of free radicals that can lead to cellular and tissue damage. This process may contribute to weight loss and alterations in performance (Ferreira and Matsubara 1997). Increases in oxidant generation are moderated by antioxidants such as catalase (CAT), superoxide dismutase (SOD) and glutathione peroxidase (GPx), which neutralize free radicals, preventing or reducing their deleterious effects on cells and tissues (Halliwell and Whiteman 2004).

Minerals are present in all cells and body tissues, where they serve a wide variety of functions. The concentrations of these minerals vary according to their requirements, and they are generally maintained within narrow limits for functional activity and tissue integrity in order to maintain satisfactory levels of growth, health, and animal productivity (Olson 2007). Among these micronutrients, zinc ( $\mathrm{Zn})$ and diphenyl diselenide $(\mathrm{PhSe})_{2}$ deserve particular mention. During weaning, reserves of $\mathrm{Zn}$ and selenium in calves are practically nonexistent. The animal depends on feed and roughage to meet the high requirements for these minerals. However, stress at weaning alters basal metabolism, protein synthesis, and immune system function, reducing animal performance. Reversing or minimizing this situation, as well as making the animal seek food is important to ensure calf development (Sundrum 2015). Selenium protects cell membranes from oxidative degeneration (Smith et al. 1986). Since the 1980s, investigators have shown that dairy cow diets supplemented with selenium help maintain the body's defense mechanisms, including antibody production, cell proliferation, cytokine production, prostaglandin metabolism, and function of cells in the innate immune defense system (Smith et al. 1986).

A recent study demonstrated the antioxidant potential of $(\mathrm{PhSe})_{2}$ in improving antioxidant/ oxidant status in production animals, as observed by Menezes et al. (2016) in fish supplemented for 60 days with $3 \mathrm{mg} / \mathrm{kg}(\mathrm{PhSe})_{2}$. In addition, experimental models of parasitic infections and liver damage have demonstrated the immunomodulatory and anti-inflammatory potential of $(\mathrm{PhSe})_{2}$ (Stefanello et al. 2015, Doleski et al. 2017). Therefore, we believe that selenium might improve the immune 
and antioxidant systems of calves during the preand post-weaning period.

Zinc plays an important role in animal health, as it is a cofactor for several enzymes in the antioxidant system. In addition, $\mathrm{Zn}$ is involved in the metabolism of nucleic acids, proteins and carbohydrates, as well as actively participating in the development and normal functioning of the immune system (Carvalho et al. 2003, Namazu et al. 2008). Recent studies have demonstrated the antioxidant and anti-inflammatory properties of $\mathrm{Zn}$ in prevention of increased free radical production, improved antioxidant enzyme activity (CAT, SOD and GPx) and decreased production of inflammatory cytokines (Yin et al. 2013, Yang et al. 2015), corroborating our hypothesis that treatment with Zn improves antioxidant and immune responses during the nursing period. Therefore, we believe that these treatments, alone or in combination, can improve the antioxidant and immune systems of pre- and post-weaning calves.

The objective of this study was to evaluate whether injectable administration with zinc edetate and diphenyl diselenide in weaning calves improves performance, immune responses, protein and lipid metabolism, and oxidative/antioxidant status.

\section{MATERIALS AND METHODS}

\section{PRODUCTS}

Diphenyl diselenide ( $\mathrm{PhSe})_{2}$ (99.9\%) was purchased from Sigma-Aldrich (St. Louis, MO, USA). $(\mathrm{PhSe})_{2}$ was diluted dimethylsulfoxide (DMSO). Zinc edetate was purchased from Biogenesis.

\section{ANIMALS}

The experiment was conducted on a farm located in the city of Tunápolis, Santa Catarina, Brazil. Twenty-four male Holstein breed calves were salvaged from local dairy farms who typically remove males after birth. The animals used in this study arrived on the farm on their first day of life, after having ingested only colostrum during the first hours of life on the farm of origin. The animals weighed an average of $40 \pm 5.2 \mathrm{~kg}$ at birth.

All the calves were housed in a closed shed, two calves per stalls, with concrete floors and wooden beds. They remained there until 60 days of life (from weaning). Then, the animals were taken to an open area, with collective bays and beaten dirt floors. The calves' concentrate-based diet (Table I) contained milk replacer until 60 days of life. Hay and water ad libitum together with concentrate was also available starting on the first day of life. From 60 days until slaughter the diet was based on $16 \%$ protein concentrate and corn silage.

\section{EXPERIMENTAL DESIGN}

The animals were divided into four groups: $(\mathrm{PhSe})_{2}, \mathrm{Zn},(\mathrm{PhSe})_{2}+\mathrm{Zn}$, and control. Each group had six calves at 50 days of life. The animals in the $(\mathrm{PhSe})_{2}$ group received a subcutaneous injection of $3 \mu \mathrm{mol} / \mathrm{kg}(\mathrm{PhSe})_{2}$. Calves in the $\mathrm{Zn}$ group received a subcutaneous dose of $1 \mathrm{mg} / \mathrm{Kg}$ zinc edetate. Animals in the $(\mathrm{PhSe})_{2}+\mathrm{Zn}$ group received a combination of both mineral preparations at the same dose and the same route of administration. The control group was not supplemented with minerals. Minerals were administered on days of life 50 (10 days prior to weaning) and 70 (10 days after weaning). That is, there were two applications at 20-day intervals.

Experimental protocol was approved by the Animal Welfare Committee of the State University of Santa Catarina (UDESC), under number: 7646040416.

\section{WEIGHING}

Animals were weighed on days of life 50, 70, 90, 150, 210, 270 and 360 (day of slaughter) using a digital scale. 
TABLE I

Diet provided to animals from birth to slaughter.

\begin{tabular}{|c|c|c|c|c|c|}
\hline \multirow{2}{*}{ Ingredients } & \multicolumn{4}{|c|}{ Age of animals (day) } & \multirow[b]{2}{*}{151 to 330} \\
\hline & 0 to 40 & 41 to 55 & 56 to 60 & 61 to 150 & \\
\hline Dry matter intake/live weight (\%) & 3.0 & 3.0 & 3.0 & 2.8 & 2.8 \\
\hline Milk replacer $(\mathrm{ml})$ & 4000 & 2000 & 1000 & - & - \\
\hline Commercial concentrate, $24 \% \mathrm{CP}$ & ad libitum & ad libitum & - & - & - \\
\hline Commercial concentrate, $16 \% \mathrm{CP}(\mathrm{Kg})$ & - & - & ad libitum & 4.0 & 7.0 \\
\hline Corn silage, whole plant (kg) & - & - & ad libitum & ad libitum & ad libitum \\
\hline Hay, tiffton $85(\mathrm{~kg})$ & ad libitum & ad libitum & ad libitum & - & - \\
\hline \multicolumn{6}{|l|}{ Concentrate } \\
\hline Ingredients $-\%$ of inclusion & $24 \%$ & $16 \%$ & & & \\
\hline Ground corn $(\%)$ & 42.5 & 35.0 & & & \\
\hline Soybean meal (\%) & 37.5 & 10.0 & & & \\
\hline Wheat bran $(\%)$ & 10.0 & 50.0 & & & \\
\hline Nucleus initial - Growth (\%) & 10.0 & - & & & \\
\hline Nucleus termination (\%) & - & 3.0 & & & \\
\hline Commercial urea $(\%)$ & - & 2.0 & & & \\
\hline Total & 100.0 & 100.0 & & & \\
\hline
\end{tabular}

* Crude protein $(\mathrm{CP})$.

\section{SAMPLE COLLECTION}

Blood samples were collected on days of life 50,70 , and 90 by jugular venipuncture. Blood was collected in tubes without anticoagulant, containing sodium citrate and EDTA. Collection tubes without anticoagulant were used to obtain serum by centrifugation at $8000 \mathrm{rpm}$ for 10 minutes, then placed in microtubes at $-20^{\circ} \mathrm{C}$. Whole blood from tubes containing sodium citrate was also homogenized and transferred to microtubes $\left(-20^{\circ} \mathrm{C}\right)$. The collection tubes containing EDTA were used to perform the leukogram and measurement of glutathione peroxidase (GPx) activity in red blood cell (RBC) membranes. This was done by washing RBCs with PBS and centrifuging at 2500 rpm three times, until only RBCs were left. These were transferred to microtubes. All materials were labelled and stored at $-20^{\circ} \mathrm{C}$ pending analysis.

At 360 days of age, the animals were sent to the slaughterhouse. The warm carcasses were weighed and muscle fragments were obtained and stored in plastic bags at $-20^{\circ} \mathrm{C}$ until analysis. On the day of analysis, muscle fragments were weighed and allocated into test tubes. Muscle tissue was homogenized in buffer containing Tris- $\mathrm{HCl}$ 10 mmol, pH 7.2 to measure oxidant levels and antioxidant activities.

\section{HEMATOLOGIC ANALYSIS}

Leukocyte count was obtained using a semiautomatic cell counter (CELM model CC530). To obtain the white cell differential, blood smears were prepared and stained using a kit (Panotico Rápido). Subsequently, cells were identified by light microscopy.

\section{BIOCHEMICAL ANALYSIS}

Serum levels of total protein (TP) and albumin were measured using commercially-available kits, on semi-automatic equipment (Bio-2000 BioPlus ${ }^{\circledR}$ ). Globulin levels were obtained by mathematical calculation (total protein - albumin). 


\section{OXIDANT LEVELS}

Lipid peroxidation was measured as serum malondialdehyde (MDA) levels, by measuring thiobarbituric acid reactive substances (TBARS) (Jentzsch et al. 1996). Results were expressed as nanomoles malondialdehyde per milliliter of serum (nmol MDA/mL). Muscle lipid peroxidation was determined by TBARS levels, measured by the absorbance of red product at $532 \mathrm{~nm}$ according to the method described by Ohkawa et al. (1979). Values were expressed as nmol MDA/mg of protein.

Oxidation levels of 2'-7'-dichlorofluorescein (DCFH) were determined in serum and muscle homogenate as a peroxide index produced by cellular components according to the modified method of Colpo et al. (2008), in order to determine levels of reactive oxygen species (ROS) (Halliwell and Gutteridge 2007). For the assay, $10 \mu 1$ samples were incubated with DCFH $(10 \mu 1) 1 \mathrm{mM}$ at $37^{\circ} \mathrm{C}$ for 1 hour in the dark. Fluorescence was measured using $488 \mathrm{~nm}$ for excitation and $520 \mathrm{~nm}$ for emission. Fluorescence measurements were normalized for time, values and fluorescence ratios (reflecting ROS levels). Results were expressed as $\mathrm{U} \mathrm{DCFH} / \mathrm{mL}$ of serum and tissue.

\section{ANTIOXIDANT ENZYMES}

Serum and tissue assays were used to evaluate activity of antioxidant enzymes superoxide dismutase (SOD) and catalase (CAT). SOD activity was determined using spectrophotometry by measuring inhibition of autocatalytic adenochrome formation (McCord and Fridovich 1969). Results were expressed as U SOD/mg protein. CAT activity was measured using the methodology described by Aebi (1984), which determines the rate of $\mathrm{H}_{2} \mathrm{O}_{2}$ decomposition. CAT activity was expressed as nmol CAT/mg protein.

Glutathione peroxidase activity was determined in erythrocyte membranes according to the method described by Gunzler et al. (1974). Results were expressed as $\mathrm{Ug} / \mathrm{Hg}$. Muscle GPx was determined according to the method described by Paglia and Valentine (1967), in which oxidation of nicotinamide adenine dinucleotide phosphate (NADPH) was determined, and enzymatic activity was expressed in nmol oxidized NADPH/h/mg protein.

\section{NITRATE/NITRITE LEVELS}

Nitric oxide levels were determined by indirectly as levels of NOx (nitrate/nitrite) using a colorimetric reaction, considered the standard technique for measuring $\mathrm{NO}_{2}$ levels (Dusse et al. 2005).

\section{STATISTICAL ANALYSIS}

For each group and day of observation, all parameters were tested for normality using the Shapiro-Wilk test. Skewness, kurtosis and homogeneity were evaluated by the Levene test. Log transformation was applied when needed. One-way ANOVA was used to analyze all parameters that showed difference, comparing groups at each time period (day 1, day 20, and day 40 ), for weight related measurements (day 1, day 20 , day 40 , day 100 , day 160 , day 220 , and day 300). For post hoc testing, Tukey's test was used accordingly. Significant difference was assumed if $P<0.05$. The statistical analysis was performed using R-language, v.3.1, R Development Core Team 2012.

\section{RESULTS}

WEIGHT

The group treated with $(\mathrm{PhSe})_{2}$ gained more weight compared with other groups on day 220 of the experiment (day of life 270). However, there were no differences among groups at the other time points or at the end of the experiment (Figure 1).

\section{LEUKOGRAM}

On day 20 of the experiment, animals treated with $\mathrm{Zn}$ and those treated with the combination of $(\mathrm{PhSe})_{2}$ 


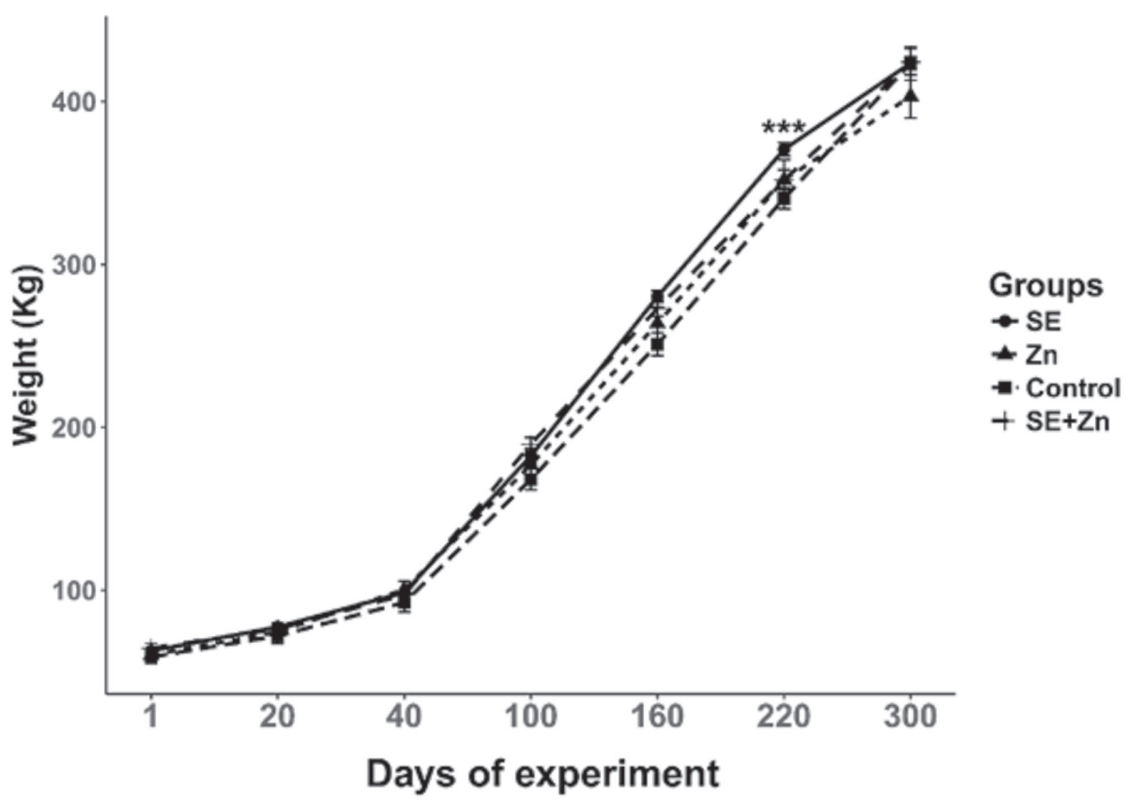

Figure 1 - Distribution by group of weigh in newborn calves. Each day of sampling the mean and standard deviation of each variable are been represented. ${ }^{* * *} P<0.001$ and represents significant differences between groups. Note: day 1 of experiment correspond at day 50 of life.

and $\mathrm{Zn}$ had greater numbers of total leukocytes and lymphocytes than did the control group. On day 40, the groups treated with $(\mathrm{PhSe})_{2}$ and $(\mathrm{PhSe})_{2}+\mathrm{Zn}$ had lower numbers of total leukocytes and lymphocytes than did the control group. On day 40, monocyte levels were lower in all the treatment groups compared with control. There were no differences in neutrophil or eosinophil counts among groups at any evaluated time point (Table II).

\section{SERUM BIOCHEMISTRY}

On day 20, serum total protein levels were greater in the group treated with the combination of $(\mathrm{PhSe})_{2}$ and $\mathrm{Zn}$, compared with control. On day 40, total protein levels were lower in the $(\mathrm{PhSe})_{2}$ group compared with control. On day 40, albumin and globulin levels were lower in the group treated with $(\mathrm{PhSe})_{2}$ compared with control. In addition, on day 20 , the combination of $(\mathrm{PhSe})_{2}$ and $\mathrm{Zn}$ gave greater values of globulin compared with control (Table III).

\section{OXIDANT STATUS AND SERUM ANTIOXIDANTS}

The mineral combination group $\left((\mathrm{PhSe})_{2}+\mathrm{Zn}\right)$ have lower values of TBARS on day of life 70 (day 20 of the experiment) compared to the other groups $(P<0.05)$. Similar, ROS levels were lower in the $(\mathrm{PhSe})_{2}$ and $(\mathrm{PhSe})_{2}+\mathrm{Zn}$ groups compared with control $(P<0.05$, Table IV).

On days 20 and 40 of the experiment, the mineral combination group $\left((\mathrm{PhSe})_{2}+\mathrm{Zn}\right)$ caused an increase in whole blood SOD activity, compared with the other groups. On day 20 of the experiment, GPx activity was greater in the $(\mathrm{PhSe})_{2}$ and $(\mathrm{PhSe})_{2}+\mathrm{Zn}$ groups, as well as in all supplemented groups at day 40, when compared to control (Table IV).

\section{NITRATE/NITRITE}

On experiment day 40 (that is, day of life 90 ), supplemented animals had higher levels of NOx $(P$ $<0.05)$ compared with the control group (Table II). 
TABLE II

Mean and standard deviation of blood components for each group at the day 1, 20 and 40 of the experiment. Different letters mean significant difference between groups.

\begin{tabular}{|c|c|c|c|c|c|c|}
\hline \multirow{2}{*}{ Variable } & \multirow{2}{*}{ Days } & \multicolumn{5}{|c|}{ Mean \pm standard deviation } \\
\hline & & $(\mathrm{PhSe})_{2}$ & Zn & $(\mathrm{PhSe})_{2}+\mathrm{Zn}$ & Control & $P$-value \\
\hline \multirow{3}{*}{ Leukocytes $\left(\times 10^{3} \mu \mathrm{L}\right)$} & 1 & $8.49 \pm 3.27$ & $7.65 \pm 3.40$ & $7.67 \pm 2.61$ & $9.18 \pm 0.68$ & 0.77 \\
\hline & 20 & $9.86 \pm 0.44^{\mathrm{bc}}$ & $16.08 \pm 6.91 \mathrm{a}$ & $12.84 \pm 4.30^{\mathrm{ab}}$ & $7.56 \pm 2.37^{\mathrm{c}}$ & 0.03 \\
\hline & 40 & $6.84 \pm 0.87^{\mathrm{c}}$ & $12.89 \pm 4.75^{\mathrm{ab}}$ & $9.77 \pm 1.53^{b}$ & $15.09 \pm 4.38^{\mathrm{a}}$ & 0.006 \\
\hline \multirow{3}{*}{ Neutrophils $\left(\times 10^{3} \mu \mathrm{L}\right)$} & 1 & $2.55 \pm 1.42$ & $2.50 \pm 1.21$ & $2.53 \pm 1.16$ & $2.81 \pm 1.59$ & 0.98 \\
\hline & 20 & $3.44 \pm 0.88$ & $5.32 \pm 2.44$ & $4.08 \pm 10.87$ & $2.96 \pm 1.63$ & 0.14 \\
\hline & 40 & $2.29 \pm 0.76$ & $3.62 \pm 1.44$ & $3.58 \pm 1.32$ & $3.98 \pm 1.65$ & 0.24 \\
\hline \multirow{3}{*}{ Lymphocytes $\left(\times 10^{3} \mu \mathrm{L}\right)$} & 1 & $5.73 \pm 1.93$ & $5.19 \pm 2.23$ & $4.91 \pm 1.65$ & $5.89 \pm 1.37$ & 0.81 \\
\hline & 20 & $5.86 \pm 1.11^{\mathrm{bc}}$ & $9.69 \pm 5.33^{\mathrm{a}}$ & $7.96 \pm 2.95^{\mathrm{ab}}$ & $3.82 \pm 1.13^{\mathrm{c}}$ & 0.04 \\
\hline & 40 & $4.22 \pm 0.42^{\mathrm{c}}$ & $8.50 \pm 3.87^{\mathrm{ab}}$ & $5.59 \pm 0.40^{\mathrm{bc}}$ & $9.68 \pm 4.16^{\mathrm{a}}$ & 0.02 \\
\hline \multirow{3}{*}{ Monocytes $\left(\mathrm{x} 10^{3} \mu \mathrm{L}\right)$} & 1 & $0.20 \pm 0.13$ & $0.16 \pm 0.06$ & $0.20 \pm 0.12$ & $0.42 \pm 0.31$ & 0.13 \\
\hline & 20 & $0.51 \pm 0.39$ & $1.02 \pm 0.42$ & $0.78 \pm 0.89$ & $0.73 \pm 0.53$ & 0.60 \\
\hline & 40 & $0.32 \pm 0.15^{\mathrm{b}}$ & $0.76 \pm 0.48^{\mathrm{b}}$ & $0.60 \pm 0.58^{\mathrm{b}}$ & $1.38 \pm 0.45^{\mathrm{a}}$ & 0.01 \\
\hline \multirow{3}{*}{ Eosinophils $\left(\mathrm{x} 10^{3} \mu \mathrm{L}\right)$} & 1 & $0.04 \pm 0.05$ & $0.04 \pm 0.09$ & $0.02 \pm 0.04$ & $0.07 \pm 0.07$ & 0.71 \\
\hline & 20 & $0.06 \pm 0.05$ & $0.05 \pm 0.07$ & $0.02 \pm 0.04$ & $0.05 \pm 0.08$ & 0.75 \\
\hline & 40 & $0.01 \pm 0.03$ & $0.01 \pm 0.03$ & $0.00 \pm 0.00$ & $0.05 \pm 0.12$ & 0.59 \\
\hline
\end{tabular}

Note: Mean with different letters on the same line shows significant difference between groups $(P<0.05)$.

\section{MUSCLE OXIDANTS/ANTIOXIDANTS}

Muscle levels of TBARS in animals treated with the mineral combination $(\mathrm{PhSe})_{2}+\mathrm{Zn}$ were lower compared with control, while GPx activity was higher. Carcass yield, ROS levels, and SOD and CAT activities did not differ among groups (Table V).

\section{DISCUSSION}

Stress of weaning is considered critical for animal production, as it may compromise the calf immune system and delay development. An analysis of the productive performance in beef cattle showed that calf mortality from birth to weaning represented $53.7 \%$ of the general mortality occurring in the herd (Alvasen et al. 2012). It is important to emphasize that many minerals are antioxidant enzyme cofactors that augment immune defense and promote animal health (McDonald 2002). Selenium participates in several processes, especially antioxidant and anti-inflammatory systems (Kim et al. 2014). In a study by Mandal et al. (2007), zinc supplementation improved cellular and humoral immune responses. Our experiment verified that mineral supplementation activated the antioxidant system, that is, it increased the 
TABLE III

Mean and standard deviation of blood components for each group at the day 1, 20 and 40 of the experiment. Different letters mean significant difference between groups.

\begin{tabular}{|c|c|c|c|c|c|c|}
\hline \multirow{2}{*}{ Variable } & \multirow{2}{*}{ Days } & \multicolumn{5}{|c|}{ Mean \pm standard deviation } \\
\hline & & $(\mathrm{PhSe})_{2}$ & Zn & $(\mathrm{PhSe})_{2}+\mathrm{Zn}$ & Control & $P$-value \\
\hline \multirow{3}{*}{ Total protein $(\mathrm{g} / \mathrm{dL})$} & 1 & $4.44 \pm 0.62$ & $4.76 \pm 0.56$ & $5.04 \pm 0.29$ & $4.94 \pm 0.67$ & 0.36 \\
\hline & 20 & $6.14 \pm 1.01^{\mathrm{ab}}$ & $5.76 \pm 0.98^{\mathrm{ab}}$ & $6.82 \pm 0.95^{\mathrm{a}}$ & $5.06 \pm 0.56^{\mathrm{b}}$ & 0.05 \\
\hline & 40 & $5.82 \pm 0.6^{\mathrm{b}}$ & $7.98 \pm 1.24^{\mathrm{a}}$ & $6.92 \pm 0.87^{\mathrm{ab}}$ & $7.18 \pm 0.99^{\mathrm{a}}$ & 0.04 \\
\hline \multirow{3}{*}{ Albumin $(\mathrm{g} / \mathrm{dL})$} & 1 & $2.58 \pm 0.68$ & $2.62 \pm 0.43$ & $3.14 \pm 0.97$ & $2.86 \pm 0.22$ & 0.50 \\
\hline & 20 & $3.84 \pm 0.38$ & $3.86 \pm 0.57^{\mathrm{c}}$ & $3.14 \pm 0.71$ & $3.40 \pm 0.46$ & 0.14 \\
\hline & 40 & $3.50 \pm 0.88^{\mathrm{a}}$ & $2.84 \pm 0.44^{\mathrm{ab}}$ & $2.96 \pm 0.15^{\mathrm{ab}}$ & $2.76 \pm 0.24^{b}$ & 0.05 \\
\hline \multirow{3}{*}{ Globulin (g/dL) } & 1 & $1.86 \pm 1.01$ & $2.14 \pm 0.71$ & $1.90 \pm 1.10$ & $2.08 \pm 0.50$ & 0.97 \\
\hline & 20 & $2.30 \pm 1.13^{\mathrm{bc}}$ & $1.90 \pm 1.02^{\mathrm{c}}$ & $3.68 \pm 0.65^{\mathrm{a}}$ & $1.66 \pm 0.18^{\mathrm{c}}$ & 0.05 \\
\hline & 40 & $2.32 \pm 1.30^{\mathrm{b}}$ & $5.14 \pm 1.97^{\mathrm{a}}$ & $3.96 \pm 0.90^{\mathrm{ab}}$ & $4.42 \pm 1.06^{\mathrm{a}}$ & 0.03 \\
\hline \multirow{3}{*}{ NOx $(\mu \mathrm{M} / \mathrm{mL})$} & 1 & $20.60 \pm 0.96$ & $21.43 \pm 5.85$ & $22.69 \pm 2.47$ & $21.85 \pm 2.07$ & 0.80 \\
\hline & 20 & $22.14 \pm 5.78$ & $22.12 \pm 1.36$ & $25.92 \pm 3.31$ & $21.20 \pm 5.52$ & 0.21 \\
\hline & 40 & $22.33 \pm 1.70^{\mathrm{b}}$ & $26.27 \pm 3.89^{\mathrm{a}}$ & $27.64 \pm 3.09^{\mathrm{a}}$ & $18.73 \pm 3.54^{\mathrm{b}}$ & 0.03 \\
\hline
\end{tabular}

Note: Mean with different letters on the same line shows significant difference between groups $(P<0.05)$.

activity of SOD and GPx. GPx is responsible for detoxifying harmful compounds (John et al. 2005), and SOD controls the formation of free radicals and non-radical species that are linked to oxidative damage (Ferreira and Matsubara 1997).

In the present study, SOD activity was significantly higher in the combined group $\left((\mathrm{PhSe})_{2}\right.$ $+\mathrm{Zn}$ ) compared with the other groups. This is probably because SOD uses zinc and selenium as cofactors (Vincent et al. 2007, Bianchi and Antunes 1999). In a study of Jersey calves and crossbreeds (Jersey x Holstein), serum selenium increased along with an increase in GPx activity when selenium was administered directly into the abomasum (Salles et al. 2014). We observed an increase in glutathione peroxidase (GPx) activity with administration of selenium or combination of minerals $\left((\mathrm{PhSe})_{2}+\right.$ $\mathrm{Zn})$. This result may be explained by the fact that selenium is involved in selenoproteins such as GPx (Hoekstra 1975). It is well known that selenium potentiates the activity of selenoproteins (Ghisleni et al. 2003, Nogueira et al. 2003, Savegnago et al. 2007).

In the present study, a reduction in TBARS levels was observed when the two minerals were given together $\left((\mathrm{PhSe})_{2}+\mathrm{Zn}\right)$, suggesting a reduction in lipid peroxidation. Zinc and selenium deficiencies predispose cells to oxidative stress, so that oxidants are not neutralized (Yatoo et al. 2013). The negative effects on animal health are mediated by damage to cells and tissues by free radicals or other oxidizing agents. Mineral supplementation can prevent oxidant stress, as has been observed in other studies (Castillo et al. 2006). The use of selenium has been much studied, but unlike most other essential mineral supplements, selenium has a narrow range between deficiency and toxicity (MacDonald et al. 1981, Abdelrahman and Kincaid 1995). Studies in several animal's species have shown toxic effects of selenium as $(\mathrm{PhSe})_{2}$ (Rosa et al. 2007), but no observed in study current. 
TABLE IV

Mean and standard deviation of blood components for each group at the day 1, 20 and 40 of the experiment.

\begin{tabular}{|c|c|c|c|c|c|c|}
\hline \multirow{2}{*}{ Variable } & \multirow{2}{*}{ Days } & \multicolumn{5}{|c|}{ Mean \pm standard deviation } \\
\hline & & $(\mathrm{PhSe})_{2}$ & Zn & $(\mathrm{PhSe})_{2}+\mathrm{Zn}$ & Control & $P$-value \\
\hline \multirow{3}{*}{$\begin{array}{l}\text { TBARS (nmol } \\
\text { MDA/mL) }\end{array}$} & 1 & $\begin{array}{c}76.08 \pm \\
14.54\end{array}$ & $\begin{array}{c}66.02 \pm \\
11.34\end{array}$ & $73.01 \pm 9.56$ & $81.04 \pm 12.31$ & 0.82 \\
\hline & 20 & $\begin{array}{l}82.97 \pm \\
20.74^{\mathrm{a}}\end{array}$ & $\begin{array}{c}85.28 \pm \\
13.49^{\mathrm{a}}\end{array}$ & $55.47 \pm 9.32^{\mathrm{b}}$ & $80.42 \pm 7.70^{\mathrm{a}}$ & 0.01 \\
\hline & 40 & $\begin{array}{l}70.90 \pm \\
12.97^{\mathrm{b}}\end{array}$ & $\begin{array}{l}59.49 \pm \\
13.30^{\mathrm{b}}\end{array}$ & $60.33 \pm 17.12^{b}$ & $90.02 \pm 6.32^{\mathrm{a}}$ & 0.01 \\
\hline \multirow{3}{*}{$\begin{array}{c}\text { ROS (U DCFH/ } \\
\text { mL) }\end{array}$} & 1 & $8.55 \pm 1.36$ & $7.20 \pm 3.29$ & $9.64 \pm 1.14$ & $9.79 \pm 3.07$ & 0.33 \\
\hline & 20 & $7.48 \pm 1.16^{\mathrm{b}}$ & $8.41 \pm 0.31^{\mathrm{b}}$ & $8.64 \pm 1.14^{\mathrm{b}}$ & $13.17 \pm 3.76^{\mathrm{a}}$ & 0.002 \\
\hline & 40 & $9.78 \pm 1.01^{\mathrm{b}}$ & $7.77 \pm 1.46^{\mathrm{b}}$ & $9.35 \pm 1.97^{\mathrm{b}}$ & $12.05 \pm 2.05^{\mathrm{a}}$ & 0.01 \\
\hline \multirow{3}{*}{$\begin{array}{l}\text { SOD (U SOD/mg } \\
\text { de protein) }\end{array}$} & 1 & $11.48 \pm 4.38$ & $17.14 \pm 8.41$ & $17.10 \pm 12.30$ & $13.54 \pm 7.79$ & 0.67 \\
\hline & 20 & $14.74 \pm 3.13^{\mathrm{c}}$ & $\begin{array}{l}21.85 \pm \\
3.24^{\mathrm{ab}}\end{array}$ & $24.40 \pm 4.05^{\mathrm{a}}$ & $18.41 \pm 1.23^{\mathrm{b}}$ & 0.01 \\
\hline & 40 & $16.70 \pm 4.20^{\mathrm{b}}$ & $\begin{array}{c}14.70 \pm \\
3.31^{\mathrm{b}}\end{array}$ & $23.32 \pm 4.33^{\mathrm{a}}$ & $13.58 \pm 3.90^{\mathrm{b}}$ & 0.005 \\
\hline \multirow{3}{*}{$\begin{array}{c}\text { GPx }(\mathrm{nmol} \\
\text { NADPH } \\
\text { oxidated/h/mg } \\
\text { protein) }\end{array}$} & 1 & $\begin{array}{l}457.39 \pm \\
50.03\end{array}$ & $\begin{array}{l}517.83 \pm \\
62.15\end{array}$ & $491.4 \pm 118.82$ & $397.94 \pm 168.38$ & 0.37 \\
\hline & 20 & $\begin{array}{l}476.4 \pm \\
55.56^{\mathrm{a}}\end{array}$ & $\begin{array}{l}292.9 \pm \\
133.06^{\mathrm{b}}\end{array}$ & $485.08 \pm 52.6^{\mathrm{a}}$ & $245.0 \pm 100.1^{\mathrm{b}}$ & $<0.001$ \\
\hline & 40 & $\begin{array}{c}491.97 \pm \\
67.5^{\text {ab }}\end{array}$ & $\begin{array}{c}535.18 \pm \\
82.30^{\mathrm{a}}\end{array}$ & $436.80 \pm 36.7^{\mathrm{b}}$ & $349.86 \pm 58.50^{c}$ & 0.001 \\
\hline
\end{tabular}

Note: Mean with different letters on the same line shows significant difference between groups $(P<0.05)$.

The stress of weaning rapidly accelerates the consumption of zinc by animals. The main consequence of this is metabolic alteration, which may reduce the need for protein synthesis, damaging animal performance (Sundrum 2015). Our total protein result was due to effects on globulins: when zinc was used, there was an increase in the total protein serum level. A study by Sundrum (2015) showed that single-dose supplementation with zinc in weaning calves increased protein synthesis, probably because more available zinc augmented the immune system, specifically acute phase proteins and immunoglobulins.
Lymphocytes and monocytes digest antigens recognized as foreign threats the immune system (Miller and Slebodzinska 1992, Balakrishnan and Adams 1995). Brunetto et al. (2007) reported that zinc deficiency resulted in extensive damage to $\mathrm{T}$ lymphocytes due to alteration in cell synthesis, resulting in immunosuppression. In our study, there was an increase in the number of leukocytes, lymphocytes, and monocytes when zinc and selenium were administered together. Various immune cells and their phagocytic activities may be directly affected by mineral deficiency, and supplementation may stimulate the immune system (Yatoo et al. 2013). 
TABLE V

Mean and standard deviation of biochemical muscle tissue for each group at the slaughterhouse, carcass yield, ROS, TBARS, GPx, SOD and CAT.

\begin{tabular}{|c|c|c|c|c|c|}
\hline \multirow{2}{*}{ Variable } & \multicolumn{5}{|c|}{ Mean \pm standard deviation } \\
\hline & $(\mathrm{PhSe})_{2}$ & $\mathrm{Zn}$ & $(\mathrm{PhSe})_{2}+\mathrm{Zn}$ & Control & $P$-value \\
\hline Carcass yield (\%) & $47.82 \pm 4.20$ & $51.46 \pm 6.67$ & $49.36 \pm 0.98$ & $49.54 \pm 2.74$ & 0.44 \\
\hline ROS(U DCFH/mL) & $115.66 \pm 19.25$ & $93.94 \pm 12.89$ & $111.50 \pm 24.59$ & $121.52 \pm 17.28$ & 0.16 \\
\hline $\begin{array}{l}\text { TBARS (nmol MDA/mg } \\
\text { of protein) }\end{array}$ & $2.54 \pm 0.69^{\mathrm{cb}}$ & $2.81 \pm 0.40^{\mathrm{b}}$ & $2.11 \pm 0.39^{\mathrm{c}}$ & $3.66 \pm 0.42^{\mathrm{b}}$ & 0.01 \\
\hline $\begin{array}{c}\text { GPx (nmol NADPH } \\
\text { oxidated/h/mg protein) }\end{array}$ & $9.89 \pm 3.69^{c}$ & $11.66 \pm 3.69^{\mathrm{bc}}$ & $22.50 \pm 4.05^{\mathrm{a}}$ & $16.02 \pm 4.04^{\mathrm{b}}$ & 0.001 \\
\hline $\begin{array}{l}\mathrm{SOD}(\mathrm{U} \mathrm{SOD} / \mathrm{mg} \text { de } \\
\text { protein) }\end{array}$ & $2.57 \pm 0.71$ & $2.95 \pm 0.34$ & $3.17 \pm 0.94$ & $2.19 \pm 0.23$ & 0.10 \\
\hline $\begin{array}{l}\text { CAT(nmol CAT/mg } \\
\text { protein) }\end{array}$ & $5.97 \pm 0.97$ & $6.42 \pm 1.59$ & $7.66 \pm 1.96$ & $5.87 \pm 0.72$ & 0.20 \\
\hline
\end{tabular}

Note: Mean with different letters on the same line shows significant difference between groups $(P<0.05)$.

We observed positive responses to minerals in muscle tissue, in the form of decreasing lipid peroxidation (TBARS) and augmentation of GPx activity. This was likely related to zinc and selenium acting on the cellular antioxidant system by decreasing free radicals (Baraboi and Shestakova 2004). Selenium deficiency caused muscle degeneration, including myocardial necrosis, due to high levels of polyunsaturated fatty acids, mainly delivered via concentrate to the animals, causing tissue damage by free radicals (Enjalbert 2009).

\section{CONCLUSIONS}

Injectable supplementation with selenium and zinc in calves during the pre- and post-weaning period had substantial effects on the animals' development. Zinc potently stimulated the immune-system while selenium had important anti-inflammatory action. When used in combination $\left((\mathrm{PhSe})_{2}+\mathrm{Zn}\right)$, the minerals activated the cellular antioxidant system, reducing the harmful action of free radicals and stimulating the activity of various immune cells.

\section{AUTHOR CONTRIBUTIONS}

Santos was the executor of the project, involved in all research stages, finalized with the writing of the scientific article; Boito, Klauck, Reis, Gebert, Glombowsky, Biazus and Berwanger were authors who were involved in the construction of the project, field experiment, sample collection, and laboratory analysis on the day of collection; Bottari, Sousa and Baldissera were involved in the laboratory analysis related to biochemistry (oxidants and antioxidants) and immune response, as well as also participated in the writing of the manuscript; Machado participated in the experimental design of the project, statistical analysis, and writing of the article; Leal and Da Silva were the creators and coordinators of the project, participating in all stages of the experiment, as well as contributing to the writing of this manuscript.

\section{REFERENCES}

ABDELRAHMAN MM AND KINCAID RL. 1995. Effect of selenium supplementation of cows on maternal transfer 
of selenium to fetal and newborn calves. J Dairy Sci 78: 625-630.

AEBI H. 1984. Catalase in vitro. Methods Enzymol 105: 121126.

ALVASEN K, MORK MJ, SANDGREN CH, THOMSEN PT AND EMANUELSON U. 2012. Herd-level risk factors associated with cow mortality in Swedish dairy herds. J Dairy Sci 95: 4352-4362.

BALAKRISHNAN K AND ADAMS LE. 1995. The role of the lymphocyte in an immune response. Immunol Invest 24: 233-244.

BARABOI VAAND SHESTAKOVA EN. 2004. Selenium: the biological role and antioxidante activity. Ukr Biokhim $\mathrm{Zh}$ 76: 23-32.

BIANCHI MLAND ANTUNES LMG. 1999. Radicais livres e os principais antioxidantes da dieta. Rev Nutr 65: 123-130.

BIONDI P, SCOTT WN AND FREITAS EAN. 1984. Criação e produção de bovinos machos de raças leiteiras para o corte. Zootecnia 22: 281-296.

BRAGA AP, RIBEIRO HU, CÂMARA FA AND BRAGA ZCAC. 2006. Desempenho de bezerros mestiços leiteiros submetidos a diferentes tipos de aleitamento artificial. Rev Caatinga 19: 245-249.

BRUNETTO MA, GOMES MOS, JEREMIAS JT, OLIVEIRA LD AND CARCIOFI AC. 2007. Imunonutrição: o papel da dieta no restabelecimento das defesas naturais. Acta Sci Vet 35: 230-232.

CARVALHO FAN, BARBOSA FA AND MCDOWELL LR. 2003. Nutrição de bovinos a pasto. Belo Horizonte, PapelForm, Editora Gráfica, p. 438.

CASTILLO C, HERNANDEZ J, VALVERDE I, PEREIRA V, SOTILLO J, LÓPEZ AM AND BENEDITO JL. 2006.

Plasma malondialdehyde (MDA) and total antioxidant status (TAS) during lactation in dairy cows. Res Vet Sci 80: 133-139.

COLPO E ET AL. 2008. A single high dose of ascorbic acid and iron is not correlated with oxidative stress in healthy volunteers. Ann Nutr Metab 53: 79-85.

DAVIS CL AND DRACKLEY JK. 1998. The development, nutrition, and management of young calf: Iowa: State University, p. 339.

DOLESKI PH, TEN CATEN MV, PASSOS DF, CASTILHOS LG, LEAL DBR, MACHADO VS, BOTTARI NB, VOGEL FF, MENDES RE AND DA SILVA AS. 2017. Toxoplasmosis treatment with diphenyl diselenide in infected mice modulates the activity of purinergic enzymes and reduces inflammation in spleen. Exp Parasitol 181: 7-13.

DUSSE LM, SILVA RM, VIEIRA LM AND CARVALHO MG. 2005. Does plasma nitric determination by the Griess reaction reflect nitric oxide synthesis? Clin Chim Acta 362: 195-197.
ENJALBERT F. 2009. The relationship between trace elements status and health in calves. Revue Med Vet 160: 429-435.

FERREIRA ALA AND MATSUBARA LS. 1997. Radicais livres: conceitos, doenças relacionadas, sistema de defesa e estresse oxidativo. Rev Ass Med Bras 43: 61-68.

GHISLENI G, PORCIUNCULA LO, CIMAROSTI H, ROCHA JBT, SALBEGO CG AND SOUZA DO. 2003. Diphenyl diselenide protect rat hippocampal slices submitted to oxygen-glucose deprivation and diminishes inducible nitric oxide synthase immunocontent. Brain Res 986: 196-199.

GÜNZLER WA, KREMERS H AND FLOHÉ L. 1974. An improved coupled test procedure for glutathione peroxidase (EC 1.11.1.9) in blood. Z Klin Chem Klin Biochem 12: 444-448.

HALLIWELL B AND GUTTERIDGE JMC. 2007. Cellular responses to oxidative stress: adaptation, damage, repair, senescence and death. In: Halliwell B and Gutteridge JMC (Eds), Free Radicals in Biology and Medicine. $4^{\text {th }}$ Edition, Oxford University Press, New York, p. 187-267.

HALLIWELL B AND WHITEMAN M. 2004. Measuring reactive species and oxidative damage in vivo and in cell culture: how should you do it and what do the results mean? Br J Pharmacol 142: 231-255.

HOEKSTRA WG. 1975. Biochemical function of selenium and its relation to vitamin E. Federation Proc J 34: 2083 2090.

JENTZSCH AM, BACHMANN H AND BIESALKSKI HK. 1996. Improved analysis of malondialdehyde in human body fluids. Free Radic Biol Med 20: 251-256.

JOHN DH, JACK UF AND IAN RJ. 2005. Glutathione transferases. Annu Rev Pharmacol Toxicol 45: 51-88.

KIM Y, KIM DC, CHO ES, KO O, KWON WY, SUH GS AND SHIN HK. 2014. Antioxidant and anti-inflammatory effects of selenium in oral buccal mucosa and small intestinal mucosa during intestinal ischemia-reperfusion injury. J Inflamm 11: 36.

KOLB E, GURTLER H, KETZ HA, SCHRODER L AND SEIDELL H. 1984. Fisiologia Veterinária. 4ª ed., Rio de Janeiro: Guanabara, 612 p.

MANDAL GP, DASS RS, ISORE DP, GARG AK AND RAM GC. 2007. Effect of zinc supplementation from two sources on growth, nutrient utilization and immune response in male crossbred cattle (Bosindicus $\times$ Bostaurus) bulls. Anim Feed Sci Technol 138: 1-12.

MCCORD JM AND FRIDOVICH I. 1969. Superoxide dismutase. An enzymatic function for erythrocuprein (hemocuprein). J Biol Chem 244: 6049-6055.

MCDONALD DW, CHRISTIAN RG, STRAUSZ KI AND ROFF J. 1981. Acute selenium toxicity in neonatal calves. Can Vet J 22: 279-281. 
MCDONALD LR. 2002. Mineral deficiencies and toxicities and their effect on beef production in developing countries. Edinburg: Pearson 6, p. 639.

MENEZES C, LEITEMPERGER J, MURUSSI C, VIERA MS, ADAIME MB, ZANELLA R AND LORO VL. 2016. Effect of diphenyl diselenide diet supplementation on oxidative stress biomarkers in two species of freshwater fish exposed to the insecticide fipronil. Fish Physiol Biochem 42: 1357-1368.

MILLER JK AND SLEBODZINSKA EB. 1992. Oxidative stress, antioxidants, and animal function. J Dairy Sci 76: 2812-2823.

NAMAZU LB, PAPESSO K, ALBUQUERQUE R, SCHAMMASS EA, TAKEARA P AND TRINDADE NETO MA. 2008. Lisina digestível e Zn quelado para frangos de corte machos: desempenho e retenção de nitrogênio na fase pré-inicial. R Bras Zootec 37: 16341640.

NOGUEIRA CW, MEOTTI FC, PILISSÃO C, ZENI G AND ROCHA JBT. 2003. Investigations into the potential neurotoxicity induced by diselenides in mice and rats. Toxicology 183: 29-37.

OHKAWA H, OHISHI N AND YAGI K. 1979. Assay for lipid peroxides in animal tissues by thiobarbituric acid reaction. Anal Biochem 95: 351-358.

OLSON KC. 2007. Management of mineral supplementation programs for cow-calf operations. Vet Clin North Am Food Anim Pract 23: 69-90.

PAGLIA DE AND VALENTINE WN. 1967. Studies on the quantitative and qualitative characterization of erythrocyte glutathione peroxidase. J Lab Clin Med 70: 158-169.

ROSA RM, ROESLER R, BRAGA AL, SAFFI J AND HENRIQUES JA. 2007. Pharmacology and toxicology of diphenyl diselenide in several biological models. Braz J Med Biol Res 40: 1287-1304.

SALLES MSV, ZANETTI MA, JUNIOR LCR, SALLES FA, AZZOLINI AECS, SOARES EM, FACCIOLI LH AND VALIM YML. 2014. Performance and immune response of suckling calves fed organic selenium. Anim Feed Sci Technol 188: 28-35.

SAVEGNAGO L, PINTO LG, JESSE CR, ALVES D, ROCHA JBT, NOGUEIRA CW AND ZENI G. 2007.
Antinociceptive properties of diphenyl diselenide: evidences for the mechanism of action. Eur J Pharmacol 555: 129-138.

SILPER DF, LANA AM, CARVALHO AU, FERREIRA CS, FRAZONI AP, LIMA JA, SATURNINO HM, REIS RB AND COELHO SG. 2014. Effects of milk replacer feeding strategies on performance, ruminal development, and metabolism of dairy calves. J Dairy Sci 97: 1016-1025.

SMITH KL, WEISS WP AND HOGAN JS. 1986. Influence of vitamin e and selenium on mastitis and milk quality in dairy cows. J Dairy Sci 80: 1728-1737.

STEFANELLO ST, DA ROSA EJF, DOBRACHINSKI F, AMARAL GP, CARVALHO NR, DA LUZ SCA, BENDER CR, SCHWAB RS, DORNELLES L AND SOARES FAA. 2015. Effect of diselenide administration in thioacetamide-induced acute neurological and hepatic failure in mice. Toxicol Res 3: 1-11.

SUNDRUM A. 2015. Metabolic disorders in the transition period indicate that the dairy cows ability to adapt is overstressed. Animals 5: 978-1020.

TZOU GG, EVERSON DO, BULL RC AND OLSON DP. 1991. Classification of beef calves as protein-deficient or thermally by discriminant analysis of blood constituents. J Anim Sci 69: 864-873.

VINCENT HK, INNES KE AND VINCENT KR. 2007. Oxidative stress and potential interventions to reduce oxidative stress in overweight and obesity. Diabetes Obesmetab 9: 813-839.

YANG JS, PERVEEN S, HA TJ, KIM SY AND YOON SH. 2015. Cyanidin-3-glucoside inhibits glutamate-induced $\mathrm{Zn}^{2+}$ signaling and neuronal cell death in cultured rat hippocampal neurons by inhibiting $\mathrm{Ca} 2+$-induced mitochondrial depolarization and formation of reactive oxygen species. Brain Res 1606: 9-20.

YATOO MI, SAXENAA, DEEPA PM, HABEAB BP, DEVI S, JATAV RS AND DIMRI U. 2013. Role of trace elements in animals: a review. Vet World 6: 963-967.

YIN LL, ZHANG Y, GUO DM, AN K, YIN MS AND CUI X. 2013. Effects of zinc on interleukins and antioxidant enzyme values in psoriasis-induced mice. Biol Trace Elem Res 155: 411-415. 